\title{
BIOACTIVITY OF EUCALYPTUS ESSENTIAL OIL
}

\author{
Deep R. Darji, Palak Sapra, Dr. Archana U. Mankad \\ Department of Botany, Bioinformatics and Climate Change Impacts Management, School of Science, Gujarat \\ University, Ahmedabad, Gujarat, India.
}

\begin{abstract}
Eucalyptus plant belongs to myrtaceae family, it commonly known as eucalyptus. In line with worldwide, it's worldwide cultivated plant. Eucalyptus plant parts has various and different bioactivities. The main chemical components of eucalyptus plant is 1,8 cineole. It has very strong medicinal properties. And other major chemical components are limonene, $\alpha$ pinene, P-Cymene, Terpine-1-ol, Globulol. Eucalyptus essential oil has strong bioactivities like antifungal, antibacterial, antioxidant, and antimycotoxigenic activities. Eucalyptus essential oil also has preservative properties. A review provides an overview of the current literature on eucalyptus essential oils mainly antifungal, antimycotoxigenic activity and their uses.
\end{abstract}

Keywords: chemical preservative, eucalyptus essential oil

\section{INTRODUCTION}

Eucalyptus, it's an outsized genus of quite 660 species of shrub and trees of the myrtaceae family [1]. Eucalyptus plant parts are having bark, leaves, flower, fruits within which they're use in numerous bio-activities. Consistent with worldwide, eucalyptus tree is that the principle of source of eucalyptus oil. Blue gum essential oils also know as volatile aromatic oil [2].

Essential oils are extracted from plants for clinically purposes became a important topics in research and industrial application likely it have some selected chemical component like 1, 8-cineole (aka cineole and eucalyptol) could be a key one component and other natural. Eucalyptol has been shown to own strong antibacterial [3], antiviral, antioxidant [4], anti-fungal action, anti-inflammatory [5]. Though the volatile oil remains recommended today for a bunch of medicinal applications, its primary use remains the treatment of cough, cold, bronchitis, and symptomatic relief of colds and congestion of the upper tract. It have some selected chemical component like 1,8-cineole (aka cineole and eucalyptol) may be a key one component and other natural.

Eucalyptus essential oil has been approved as food additive. And plant extract also employed in pharmaceutical and cosmetic industries [13]. The oil possesses widely bioactivities it including antimicrobial, fungicidal, insecticidal, herbicidal, etc.

Table-1: General data

\begin{tabular}{|l|l|}
\hline Plant name & Eucalyptus plant \\
\hline Common name & $\begin{array}{l}\text { Eucalyptus, blue gum, } \\
\text { Tasmanian blue gum, }\end{array}$ \\
\hline
\end{tabular}

\begin{tabular}{|l|l|}
\hline & southern blue gum \\
\hline Scientific name & Eucalyptus globulus \\
\hline Plant type & Tree \\
\hline Native region & Australia \\
\hline Main producers & China \\
\hline $\begin{array}{l}\text { Main economic } \\
\text { use }\end{array}$ & $\begin{array}{l}\text { Medicinal, cattle forage, } \\
\text { cosmetics, living fence, } \\
\text { timber industry }\end{array}$ \\
\hline Plant life style & Perennial \\
\hline $\begin{array}{l}\text { Main consumed } \\
\text { part }\end{array}$ & Leaves \\
\hline Growing habitat & Sub tropical region \\
\hline
\end{tabular}

(General data of Eucalyptus globulus plants)

\section{PHYTOCHEMICALS}

Eucalyptus oil has light yellowish colour oil and it has aromatic odour. The main component is 1,8-cineole and other major chemical components are limonene, $\alpha$-pinene, P-Cymene, Terpine-1-ol, Globulol.[10]

Table-2 phytochemicals structure

\begin{tabular}{|l|c|}
\hline $\begin{array}{c}\text { Chemical } \\
\text { components }\end{array}$ & Structure \\
\hline 1,8-cineole & \\
\hline limonene & \\
\hline P-pinene & \\
\hline Terpine-1-ol & \\
\hline
\end{tabular}

Chemical components 
International Journal of Engineering Applied Sciences and Technology, 2021

Vol. 5, Issue 12, ISSN No. 2455-2143, Pages 103-106

Published Online April 2021 in IJEAST (http://www.ijeast.com)

\section{BIOACTIVITY OF EUCALYPTUS OIL}

Eucalyptus oil has bioactivity such as antifungal and antimycotoxigenic activities [10].

\section{- Antifungal activity}

Table-3: Overview about antifungal activity of eucalyptus oil [10]

\begin{tabular}{|l|l|l|l|c|}
\hline \multicolumn{1}{|c|}{$\begin{array}{c}\text { Essential oil } \\
\text { form }\end{array}$} & \multicolumn{1}{|c|}{ Fungal culture } & \multicolumn{1}{c|}{ Method } & \multicolumn{1}{c|}{$\begin{array}{c}\text { MIC/ } \\
\text { inhibition }\end{array}$} & References \\
\hline Eucalyptus sp. & $\begin{array}{l}\text { Fusarium gramineruaum, } \\
\text { Fusarium asiaticum, } \\
\text { Fusarium verticillioides, } \\
\text { Fusarium oxysporum, } \\
\text { Aspergillus flavus, botrytis } \\
\text { cinerea }\end{array}$ & $\begin{array}{l}\text { Poisoned food } \\
\text { technique }\end{array}$ & $\begin{array}{l}33-75 \% \\
\text { inhibition at } \\
1000 \mu \mathrm{L} / \mathrm{L}\end{array}$ & {$[6]$} \\
\hline $\begin{array}{l}\text { Eucalyptus } \\
\text { camaldulensis }\end{array}$ & $\begin{array}{l}\text { Fusarium oxysporum, } \\
\text { Fusarium proliferatum, } \\
\text { Fusarium soloni, Fusarium } \\
\text { subglutinans, Fusarium } \\
\text { verticilloides }\end{array}$ & $\begin{array}{l}\text { Poisoned food } \\
\text { technique }\end{array}$ & $7-8 \mu \mathrm{L} / \mathrm{mL}$ & {$[7]$} \\
\hline $\begin{array}{l}\text { Eucalyptus } \\
\text { globulus }\end{array}$ & $\begin{array}{l}\text { Aspergillus parasiticus, } \\
\text { Fusarium moniliforme }\end{array}$ & Disc diffusion & $\begin{array}{l}9-27 \% \text { inhibition } \\
\text { at } 500 \mu \mathrm{L} / \mathrm{L}\end{array}$ & {$[8]$} \\
\hline $\begin{array}{l}\text { Eucalyptus } \\
\text { globulus }\end{array}$ & $\begin{array}{l}\text { Aspergillus flavus, } \\
\text { Aspergillus parasiticus }\end{array}$ & $\begin{array}{l}\text { Contact and } \\
\text { volatile assay }\end{array}$ & $\begin{array}{l}100 \% \text { inhibition } \\
\text { at } 500 \mu \mathrm{L} / \mathrm{L}\end{array}$ & {$[9]$} \\
\hline
\end{tabular}

- Antimycotoxigenic activity

Table-4: overview studies about the antimycotoxigenic properties of essential oil [10].

\begin{tabular}{|l|l|l|l|l|c|}
\hline Essential oil form & EO concentration & Mycotoxin & Method & $\begin{array}{l}\text { Mycotoxin } \\
\text { inhibition\% }\end{array}$ & References \\
\hline $\begin{array}{l}\text { Eucalyptus } \\
\text { radiata } \\
\text { (leaf oil) }\end{array}$ & $100-200 \mu \mathrm{L} / \mathrm{mL}$ & DON & HPLC, LOD:NI & $37.47-37.70$ & {$[11]$} \\
\hline $\begin{array}{l}\text { Eucalyptus } \\
\text { radiata } \\
\text { (leaf oil) }\end{array}$ & $100-200 \mu \mathrm{L} / \mathrm{mL}$ & ZEA & $\begin{array}{l}\text { HPLC, LOD:0.01 } \\
\mu \mathrm{g} / \mathrm{mL}\end{array}$ & $38.48-97.32$ & {$[12]$} \\
\hline
\end{tabular}

- Other uses

Table-4: Other uses

\begin{tabular}{|l|l|}
\hline \multicolumn{1}{|c|}{ Plants } & \multicolumn{1}{c|}{ Other uses } \\
\hline $\begin{array}{l}\text { Eucalyptus globulus } \\
\text { (eucalyptus) }\end{array}$ & -Timber: they are very tall and fast growing trees. They produce a hard wood \\
& good for timber, which can later be processed into paper, ships, railroad ties, \\
& mulch, charcoal, or bio fuel. \\
& -Oral care: They are added to make many mouthwashes and toothpastes. EO is \\
& also an ingredient in dentistry products used to sealing root canals and fillings. \\
& -Agriculture: It can also serve as forest cover for woodland crops. Dried leaves \\
& are used as feed for cattle, horses, and sheep. \\
& -Cosmetics: They are used in many beauty products. It can be found in some \\
& lotion, bubble bath solution, shower steamers, sals, soaps, salves, scrubs, \\
& deodorants, and more. \\
& -Repellent: they have insect repellents. \\
\hline
\end{tabular}

(Uses of Eucalyptus globulus plants)

- Remedies and supplements

Table-5: Remedies and supplements

\begin{tabular}{|l|l|}
\hline Plants & Remedies and supplements \\
\hline $\begin{array}{l}\text { Eucalyptus globulus } \\
\text { (eucalyptus) }\end{array}$ & $\begin{array}{l}\text {-Essential oil: Eucalyptus essential oil can reduce sinus pain } \\
\text { and swelling, as well as nasal congestion. It also can help }\end{array}$ \\
\hline
\end{tabular}


International Journal of Engineering Applied Sciences and Technology, 2021

Vol. 5, Issue 12, ISSN No. 2455-2143, Pages 103-106

Published Online April 2021 in IJEAST (http://www.ijeast.com)

\begin{tabular}{|l|l|}
\hline & reduce joint pain. \\
& -Tincture: like essential oil, eucalyptus tinctures can be \\
inhaled or applied topically. Eucalyptus tinctures are typically \\
used for decongestion due to its expectorant properties. \\
-Ointment: as a cream, eucalyptus can be applied topically to \\
relieve inflammation from joint pain and insect bites. \\
-Capsule: when taken in this form, eucalyptus acts as a highly \\
potent decongestive, helping to ease coughs and relieve sore \\
throats.
\end{tabular}

(Remedies and supplements of E. globulus plants)

- Side effects

Table-6: Side effects

\begin{tabular}{|l|l|}
\hline Plant & Side effects \\
\hline Eucalyptus globulus & - Leaves are likely safe when consumed in controlled quantities. \\
(eucalyptus) & -It is possible to get eucalyptus poisoning with over uses of essential \\
& oils. \\
& -Eucalyptus poisoning include some signs like upset stomach, \\
& dizziness, muscle weakness, difficulty breathing, nausea, vomiting, and \\
& diarrhoea.. \\
\hline
\end{tabular}

(Side effects of E. globulus plants)

\section{CONCLUSION}

In line with multipurpose source, eucalyptus plant as well as essential oil is the champion oil ever in medicinal field, pharmaceutical fields, and pharmacognosy field. It is a fine oil in research practices, phytochemicals screening. Eucalyptus oil has strong antifungal activity, antimicrobial activity and antimycotoxigenic activity and antimycotoxigenic activity. 1-8, cineole is a main chemical component of eucalyptus plant and oil. It responsible for the medicinal properties. Consistent with the trade, eucalyptus oil the most important volatile oil for medicinal use and home remedies.

\section{REFERENCES}

[1]. Hermann, R. and von Richter, O., 2012. Clinical evidence of herbal drugs as perpetrators of pharmacokinetic drug interactions. Planta medica, 78(13), pp.1458-1477.

[2]. Clarke, S., 2008. Composition of essential oils and other materials. Essential Chemistry for Aromatherapy (Second Edition). Edinburgh: Churchill Livingstone, pp.123-229.

[3]. Lo Cantore, P., Shanmugaiah, V. and Iacobellis, N.S., 2009. Antibacterial activity of essential oil components and their potential use in seed disinfection. Journal of agricultural and food chemistry, 57(20), pp.9454-9461.

[4]. Dutra, R.C., Leite, M.N. and Barbosa, N.R., 2008. Quantification of phenolic constituents and antioxidant activity of Pterodon emarginatus vogel seeds. International Journal of Molecular Sciences, 9(4), pp.606-614.

[5]. Chao, L.K., Hua, K.F., Hsu, H.Y., Cheng, S.S., Liu, J.Y. and Chang, S.T., 2005. Study on the antiinflammatory activity of essential oil from leaves of
Cinnamomum osmophloeum. Journal of Agricultural and Food Chemistry, 53(18), pp.7274-7278.

[6]. Davari, M. and Ezazi, R., 2017. Chemical composition and antifungal activity of the essential oil of Zhumeria majdae, Heracleum persicum and Eucalyptus sp. against some important phytopathogenic fungi. Journal de mycologie medicale, 27(4), pp.463-468. [7]. Gakuubi, M.M., Maina, A.W. and Wagacha, J.M., 2017. Antifungal activity of essential oil of Eucalyptus camaldulensis dehnh. against selected Fusarium spp. International journal of microbiology, 2017.

[8]. López-Meneses, A.K., Plascencia-Jatomea, M., Lizardi-Mendoza, J., Rosas-Burgos, E.C., Luque-Alcaraz, A.G. and Cortez-Rocha, M.O., 2015. Antifungal and antimycotoxigenic activity of essential oils from Eucalyptus globulus, Thymus capitatus and Schinus molle. Food Science and Technology, 35(4), pp.664-671. [9]. Vilela, G.R., de Almeida, G.S., D'Arce, M.A.B.R., Moraes, M.H.D., Brito, J.O., da Silva, M.F.D.G., Silva, S.C., de Stefano Piedade, S.M., Calori-Domingues, M.A. and da Gloria, E.M., 2009. Activity of essential oil and its major compound, 1, 8-cineole, from Eucalyptus globulus Labill., against the storage fungi Aspergillus flavus Link and Aspergillus parasiticus Speare. Journal of Stored Products Research, 45(2), pp.108-111.

[10]. Mutlu-Ingok, A., Devecioglu, D., Dikmetas, D.N., Karbancioglu-Guler, F. and Capanoglu, E., 2020. Antibacterial, antifungal, antimycotoxigenic, and antioxidant activities of essential oils: An updated review. Molecules, 25(20), p.4711.

[11] Perczak, A., Juś, K., Gwiazdowska, D., Marchwińska, K. and Waśkiewicz, A., 2019. The efficiency of deoxynivalenol degradation by essential oils under in vitro conditions. Foods, 8(9), p.403.

[12] Perczak, A., Juś, K., Marchwińska, K., Gwiazdowska, D., Waśkiewicz, A. and Goliński, P., 2016. Degradation of zearalenone by essential oils under in vitro conditions. Frontiers in microbiology, 7, p.1224. 
International Journal of Engineering Applied Sciences and Technology, 2021

Vol. 5, Issue 12, ISSN No. 2455-2143, Pages 103-106

Published Online April 2021 in IJEAST (http://www.ijeast.com)

[13] Arfao, A.T., Nola, M., Djimeli, C.L., Nougang, M.E. and Fokou, J.B., 2013. Cultivability of Salmonella typhi, Vibrio cholerae and enteropathogenic Escherichia coli in water microcosm in the presence of Eucalyptus microcorys leaves extract: effect of the concentration of leaves extract and incubation temperature. Int $J$ Res Biosci, 2(4), pp.32-46. 